\title{
Risk of urothelial cancer death among people using antihypertensive drugs - a cohort study from Finland
}

\author{
Eerik EE Santala ${ }^{1}$, Andres Kotsar ${ }^{2}$, Thea Veitonmäki ${ }^{3}$,Teuvo LJ Tammela ${ }^{1,3}$ Teemu J Murtola ${ }^{1,4}$ \\ ${ }^{1}$ Tampere University, Faculty of Medicine and Health Technology, Tampere, Finland \\ ${ }^{2}$ Tartu University Hospital, Department of Urology, Tartu, Estonia \\ ${ }^{3}$ Tampere University Hospital, Department of Urology, Tampere, Finland \\ ${ }^{4}$ Seinäjoki Central Hospital, Department of Urology, Seinäjoki, Finland
}

Key words: urothelial cancer, antihypertensive drugs, bladder cancer, risk of death, ATR-blockers

* Correspondence to: Eerik EE Santala, Tampere University, 33521 Tampere, Finland, E-mail: eerik.santala@tuni.fi 


\section{ABSTRACT}

Introduction: To analyse the association between antihypertensive (anti-HT) drug use and risk of urothelial cancer (UC) death. UC occur as bladder cancer (BCa) and upper tract urothelial carcinomas (UTUCs). Hypertension is a suggested risk factor for $\mathrm{BCa}$ and may impair disease prognosis. However it`s unclear if use of anti-HT drugs could improve prognosis of UC.

Materials and Methods: We evaluated the association between use of anti-HT drugs and UC survival among 14,065 participants diagnosed with BCa and 1080 with UTUC during 1995-2012 in Finland. We analyzed data using multivariable adjusted conditional Cox regression model.

Results: Angiotensin-receptor (ATR) blocker use before BCa diagnosis was associated with slightly decreased risk of $\mathrm{BCa}$ death (HR: $0.81 \mathrm{Cl}: 0.71-0.93)$. The association was dose-dependent and it decreased in association with elevated intensity of ATR-blocker use.

Post-diagnostic use of ATR-blockers was similarly associated with better survival compared to nonusers (HR: $0.81 \mathrm{Cl}: 0.71-0.92$. Interestingly use of calcium-channel blockers associated also with better survival and the risk of $\mathrm{BCa}$ death decreased with increasing intensity of use (HR: $0.67 \mathrm{Cl}$ : 0.52-0.86 for highest intensity).

Conclusions: Our large population- based cohort suggests decreased risk of BCa death among ATRblocker and calcium-channel blocker users. The risk association among ATR-blockers and calciumchannel blockers was dose-dependent suggesting a causal explanation. Similar risk associations are not observed for other anti-HT drug users which may suggest a direct effect of ATR blocker or calcium-channel blocker use. Further studies are needed to elucidate the potential anticancer mechanism. 


\section{INTRODUCTION}

Urothelial cancers (UC) can be divided into bladder cancer (BCa) and upper tract urothelial cancers (UTUCs). BCa is the ninth most common cancer in the world [1]. Low-grade BCa recurs often, requiring intense follow-up which makes it one of the most expensive cancers in the world. Highgrade $\mathrm{BCa}$ advances often to fatal stage causing high losses in life expectancy in the Western countries [2]. UTUCs account only for 5-10\% of urothelial carcinomas [3]. The yearly incidence of UTUC in the Western countries is estimated to be $2 / 100.000$ [4]. Urothelial cancers are more common in men than women [1]. Smoking is the most important risk factor both for BCa and UTUC $[5,6]$.

Besides smoking, also other possible risk factors for UC have been suggested. Diabetes may increase the risk of $\mathrm{BCa}$ and $\mathrm{BCa}$ death as well as increase the risk of disease recurrence in UTUC $[7,8]$. Hypertension may be a risk factor for BCa and many other cancer types, but studies are few [9], and not all studies agree [10]. Hypertension may also impair disease prognosis [9]. Still it is unknown whether use of antihypertensive drugs (anti-HT drugs) would lower the risk of BCa or improve disease prognosis. A challenge is to separate influence of anti-HT medication from that of the underlying hypertension. Another challenge is to be able to take into account simultaneous use of different drug groups and different treatments when evaluating possible effect of a single drug group.

Here we analyse BCa and UTUC-specific survival by use of different groups of antihypertensive drugs among participants with urothelial cancer in the bladder or the upper urinary tract. 


\section{MATERIALS AND METHODS}

\section{Study cohorts}

Two study cohorts were identified from the Finnish Cancer Registry (FCR), which registers virtually all cancer diagnoses in Finland through mandatory notifications and pathological reports [11]. Causes of death in Cancer Registry are obtained from national mandatory death certificate registry. Causes of death reported by clinicians in death certificates are reviewed by medical authorities and in unclear cases a forensic examination of the cause of death is mandated.

The BCa cohort consisted of 14,065 primary bladder cancer cases from Finland diagnosed during 1995-2012. Data contained information on the primary site of cancer, tumour extent at diagnosis (localized, locally advanced, advanced, unknown), date and method of diagnosis, primary treatment method (surgery, radical cystectomy, cytostatic drugs, chemotherapy, antihormonal therapy) and date and cause of death. Surgery includes radical cystectomies but also endoscopic operations such as partial removal of bladder and transurethral resection of tumour.

The UTUC cohort consisted on 1,080 participants diagnosed with primary cancers in the renal pelvis or the ureter in Finland between 1995 and 2012. The data included same information as for the BCa cohort (surgery includes radical nephro-ureterectomy but also minor surgical operations). FCR does not record tumour grade, thus it was not available.

Data on either cohort does not include tumour recurrences.

\section{Information on antihypertensive medication use}

Both study cohorts were linked to national prescription database for information on antihypertensive (anti-HT) medication use during 1995-2012. The database is maintained by the Finnish Social Insurance Institution (SII). SII provides reimbursements for physician-prescribed drug 
purchases for every Finnish citizen in outpatient setting as a part of the national health insurance. The information on each purchase includes dose, purchase date, package size and number of packages bought.

We identified each anti-HT drug by using drug-specific ATC-code (Table S1). Anti-HT drugs were categorised into five groups: angiotensin-converting enzyme (ACE)-inhibitors, angiotensinreceptor (ATR)-blockers, diuretics, beta-blockers and calcium-channel blockers.

\section{Information on co-morbidities}

Both cohorts were linked to Care Registry (HILMO) maintained by the National Institute For Health And Welfare to collect information on diagnoses and procedures conducted in study population during 1995-2013. The Registry records all diagnoses and medical procedures from in- and outpatient hospital visits in Finland. Diagnoses recorded in HILMO were used to calculate Charlson co-morbidity index for each participant [12]. Conditions used in the index calculation are listed in Table S2. COPD and kidney failure diagnoses were added separately into analysis as they may serve as potential confounding factors.

\section{Statistical analysis}

We performed separate analyses for drug usage before and after UC diagnosis in both study cohorts. We compared the risk of BCa and UTUC death between users and non-users of anti-HT drugs.

The total yearly mg amount of purchases of each anti-HT drug was calculated for each participant based on the dosing, package sizes and number of packages from each purchase. Total purchased yearly mg amount was divided by the dose corresponding to the drug specific Defined Daily Dose 
(DDD) for total number of DDDs purchased per year [13]. Each year with recorded purchases was considered as year of usage regardless of the amount purchased.

Cumulative number of years for usage and DDDs was calculated separately for each year before and after UC diagnosis. Amount of use before the diagnosis was calculated by adding together all usage between 1995 and the year of diagnosis. We evaluated intensity of use by dividing cumulative amount of DDD with cumulative number of usage years.

Post-diagnostic use was analysed as time-dependent variable to minimize immortal time bias. Time-dependent variables were formed by updating medication user status as well as cumulative amount, duration and intensity of use separately for each follow-up year after bladder cancer/UTUC diagnosis according to recorded purchases. Dose-dependence was evaluated by stratifying medication users by tertiles of DDD amount, duration and intensity of use based on the level reached on each follow-up year. After discontinuation of usage (full calendar year without any anti-HT drug purchases) the participants remained in the user category to minimize bias due to selective discontinuation of preventative medications in fatal stage of cancer. After discontinuation year cumulative tertiles of DDD amount, duration and intensity of anti-HT drug use remained the same level as before (no cumulative grow up after discontinuation).

Cox regression was used to calculate hazard ratios (HRs) and $95 \%$ confidence intervals (95\% Cis) for the risk of cancer-specific death. Time metric used was years and months since BCa or UTUC diagnosis. Follow up continued until death, emigration or the common closing date Dec $31^{\text {st }}, 2012$, whichever came first.

Cox regression analyses were adjusted for age at diagnosis, year of diagnosis, tumor extent (local or advanced), surgery, cytostatic drugs, kidney failure, COPD, Charlson co-morbidity index and use 
of statins, antidiabetic medication, non-steroidal anti-inflammatory drugs and aspirin during the follow-up.

Simultaneous use of multiple anti-HT drug groups was modelled by forming separate timedependent variables for use of each drug group, i.e. ACE-inhibitors, ATR-blockers, beta-blockers, calcium channel blockers and diuretics. These variables were included in the Cox regression model together to model simultaneous use.

Delayed association between anti-HT drug use and risk of cancer death was investigated in lag time analyses where the exposure was lagged forward in the follow-up time; analysing medication use that occurred one, three or five years before.

The data were analysed using the IBM SPSS statistics 24 program.

\section{RESULTS}

\section{Population characteristics}

Anti-HT drug use was very common in our bladder cancer cohort. Of the 14,065 participant 10,489 (75\%) had used at least one anti-HT drug before or after diagnosis; 3576 (25\%) had not used any kind of anti-HT medication (Table 1). Compared to non-users, anti-HT medication users were older at diagnosis (median age 73 years) and also used more often statins and antidiabetic medication. During the median follow-up of 4.1 years after BCa diagnosis, a total of 5550 participants (40/100) died. Of these, 2948 (21/100) died of BCa.

Among the UTUC cohort use of anti-HT drugs was also common: of 1080 participants 852 (79\%) had used anti-HT drugs while only 228 ( $21 \%)$ had not used any anti-HT medication during the follow-up. Anti-HT users were older at the time of cancer diagnosis and they used more often statins and antidiabetic medication. During the follow-up a total of 713 (66/100) participants died, 
of which $458(42 / 100)$ by UTUC. The headline other treatment in Table 1 includes all other treatment methods except surgery in both BCa or UTUC ( cytostatic drugs, cemotherapy, antihormonal therapy).

\section{Antihypertensive drug usage before UC diagnosis}

Angiotensin-receptor (ATR) blocker use before BCa diagnosis was associated with slightly decreased risk of $\mathrm{BCa}$ death (HR: $0.8095 \% \mathrm{Cl}: 0.70-0.92$ ) (Table 2). In the intensity analyses highest intensity of ATR-blocker use associated with most reduction in $\mathrm{BCa}$ death risk (HR: $0.6595 \% \mathrm{Cl}$ : 0.50-0.84). Long-time (5 years or more) use of ATR-blockers was associated with statistically significant reduction in $\mathrm{BCa}$ death risk (HR: $0.6395 \% \mathrm{Cl}: 0.50-0.79)$. On the contrary, among users of diuretics the risk increase for $\mathrm{BCa}$ death was observed in all subgroup analyses being highest with strongest intensity of use (HR: $1.2895 \% \mathrm{Cl}: 1.13-1.44)$. Diuretics were associated with increased risk of BCa death also in lag-time analyses.

In analysis stratified by gender beta-blockers were associated with slightly increased risk of BCa death in men ( $p$ for interaction $=0.003$, Table 6 ). ATR-blockers were associated with decreased risk only among women ( $\mathrm{p}$ for interaction $=0.046)$. Diuretics associated with increased risk of $\mathrm{BCa}$ death risk in both genders.

Pre-diagnostic use of ATR-blockers and calcium-channel blockers were associated with slightly decreased risk of UTUC death although the risk differences were not statistically significant (Table 2). In lag-time analyses no clear delayed risk associations between any anti-HT drug group and UTUC death was found (Table 4). 


\section{Antihypertensive drug use after the UC diagnosis}

Post-diagnostic use of ATR-blockers was similarly associated with better BCa survival compared to non-users and the risk decreased in inverse association with cumulative dose and intensity of use

(Table 3). When analysed by gender ATR-blockers associated with decreased risk of BCa death only among men ( $p$ for interaction $=0.004$, Table 6 ). Also calcium-channel blockers were associated with reduced risk of $\mathrm{BCa}$ death as the intensity of use increased (HR: $0.6795 \% \mathrm{Cl}: 0.52-0.86$ for 367 DDDs/ yr or more). However, such risk trend was not found for duration of calcium-channel blocker use (Table 5). Increased risk of BCa death by diuretics use was observed among both genders (Table 6).

Highest intensity of post-diagnostic beta-blocker use associated with slightly decreased risk of BCa death (HR: $0.7695 \% \mathrm{Cl}$ : 0.66-0.87). Diuretics associated with increased risk of $\mathrm{BCa}$ death in all intensity analyses but risk was highest in lowest intensity of use (HR: $1.6495 \% \mathrm{Cl}$ : 1.48-1.81). Risk declined to non-significant level when intensity of use increased.

In UTUC analyses most of the risk differences by anti-HT drug use were not statistically significant. Similar to $\mathrm{BCa}$, high dose as well as high-intensity use of diuretics associated with worse UTUC survival compared to non-users.

\section{Subgroup analyses}

We analysed separately the association between post-diagnostic anti-HT drug use on UC death in four subgroups stratified by potential confounding factors. The analysis was stratified by age at diagnosis, tumor extent at diagnosis, comorbidities and COPD separately and use of statins. Subgroup analyses in BCa cohort are shown in Figures 1-5. 
No effect modification by age was observed for ATR-blocker use, the risk decrease was similar among participants younger than 73 or older. The risk of BCa death among beta-blocker users, however, appeared to be modified by age; the risk was increased in the younger age group only ( $p$ for interaction $<0.001$ ). No significant effect modification by age was observed in the UTUC cohort. Tumor extent at diagnosis modified the association between beta-blocker use and cancer deaths in both study cohorts. Users of beta-blockers had increased risk of death compared to non-users among participants diagnosed with localized tumor, whereas no risk association was observed for participants with advanced disease at diagnosis ( $\mathrm{p}$ for interaction $<0.001$ for $\mathrm{BC}$ a and UTUC cohorts, respectively).

Charlson comorbidity index did not modify the risk associations in the BCa cohort. In the UTUC cohort, however, beta-blockers were associated with increased risk of cancer death only among participants with little or no co-morbidities ( $p$ for interaction $=0.005$ ). On the contrary, ATRblocker users had a decreased risk of BCa death among participants with high CCl-value ( $\mathrm{p}$ for interaction < 0.001). No effect modification by $\mathrm{CCl}$ was observed in the $\mathrm{BCa}$ cohort.

When analyzed only among COPD-diagnosed participants the risk estimates for BCa death declined into nonsignificant level but risk estimates among ATR-blocker users stayed decreased compared to non-users. When excluding COPD-participants the risk decrease among ATR-blocker users became statistically significant (HR: $0.8195 \% \mathrm{Cl}: 0.70-0.93)$.

The risk of $\mathrm{BCa}$ death was increased in beta-blocker users only among participants also using statins $(p<0.001)$. No effect modification by statin use was observed in the UTUC cohort. When stratified by year of UC diagnosis, ATR-blockers were associated with better BCa survival only among cases diagnosed in the 1990s ( $p<0.001$ ). In UTUC cohort effect modification by diagnosis year could not be evaluated. 


\section{DISCUSSION}

To our knowledge this is the first study to compare risk of death due to urothelial cancer by different groups of antihypertensive drugs.

In our BCa cohort post-diagnostic ATR-blocker use generally was associated with better BCaspecific survival compared to non-users. The association was observed in both genders, but when stratified by gender among females for pre-diagnosis usage and among males for post-diagnosis usage. The risk decrease was dose-dependent, being inversely associated with the intensity (yearly dose) of ATR-blocker use. The same dose-dependence was also observed among calcium-channel blocker users. Similar risk trend for multiple groups of antihypertensive drugs with differing mechanisms of action suggests that the common indication, treatment of hypertension may have a prognostic role in $\mathrm{BCa}$ patients. Diuretics instead associated with increased risk of BCa death in all analyses. This is likely affected by diuretics being used also for other causes besides controlling hypertension, such as oedema common in advanced cancer.

Similar risk differences were not observed in the UTUC-cohort. It has to be noted that UTUC is frequently managed with nephroureterectomy which often leads to renal insufficiency limiting medication use, for example of drugs affecting RAA-system. Therefore UTUC patients may not be able to use drugs affecting RAA-system which could explain more subtle risk associations compared to BCa cohort. However our analysis were adjusted with kidney failure so that there must be another explanation.

All anti-HT drugs except beta-blockers and some diuretics such as furosemide are first-line treatment of hypertension in Finland. Thus, it's not likely that patients using different groups of anti-HT drugs differ from each other by difficulty of hypertension. On the contrary anti-HT drugs 
are also used to treat other diseases than hypertension like coronary artery disease and kidney and heart failure, which may have a confounding effect on results particularly among beta-blocker and diuretic users. Nevertheless, adjustment for $\mathrm{CCl}$ did not remove the risk increase observed among users of diuretics and beta-blockers.

The strengths of our study are long follow-up time and large BCa-cohort consisting of all bladder cancers diagnosed in Finland between 1995-2012. Our registry-based data on medication use was exceptionally detailed and free of recall bias. We were able to take into account simultaneous use of different anti-HT drug groups and statins, NSAIDs, aspirin and antidiabetic medication and to adjust the analysis for primary treatment, as anti-HT drug users likely had more comorbidities limiting possibilities for curative-intent surgery. We also adjusted our analyses with year of diagnosis as cancer management has changed over time, possibly modifying the survival associations with anti-HT drug use.

We didn't have information on blood pressure level, i.e. on how well hypertension was managed, which may affect results if hypertension indeed was a prognostic factor. We didn't also know whether anti-HT drugs purchased were actually consumed. Our information on medication use starts on 1995 which likely causes under estimation of pre-diagnostic medication use. Also low number of BCa and UTUC deaths in our data must be considered because it limits the statistical power in subgroup analyses increasing probability for type 2 error. We didn't have information on tumour grade which may have caused confounding if anti-HT medication was associated with grade. We didn't have information on socioeconomical or lifestyle factors such as physical activity or smoking which could have served as confounders depending on their association with antihypertensive medication use and urothelial cancer survival. These factors may partly explain 
the differing results among ATR-blocker and calcium-channel blocker users compared to other anti-HT drug groups. Nevertheless, selection bias shouldn't be dose-dependent.

In conclusion ATR- blocker use was associated with better BCa survival both in pre- and postdiagnostic use. The association was dose-dependent. Also high-intensity use of beta-blockers and calcium-channel blockers associated with reduced BCa death risk which may be partly explained with better control of hypertension. Our study supports further studies on the association between ATR-blockers and BCa progression.

\section{ACKNOWLEDGMENTS}

Eerik EE Santala: none

Andres Kotsar: none

Teuvo LJ Tammela: Consultation fees from Astellas, Janssen-Cilag and Bayer AG. Investigator in clinical trials: Astellas, Bayer AG, Janssen-Cilag, Lidds Ab, Orion Pharma

Thea Veitonmäki: Consultation fee Phizer, travel support Astellas

Teemu J Murtola: Consultation fees from Astellas. Lecture fees from Janssen. 


\section{REFERENCES}

[1.] Antoni S, Ferlay J, Soerjomataram I et al. Bladder Cancer Incidence and Mortality: A Global Overview and Recent Trends. Eur Urol 2017 January 01;71(1):96-108.

[2.] Yeung C, Dinh T, Lee J. The health economics of bladder cancer: an updated review of the published literature. Pharmacoeconomics 2014 November 01;32(11):1093-1104.

[3.] Roupret M, Babjuk M, Comperat E et al. European Association of Urology Guidelines on Upper Urinary Tract Urothelial Cell Carcinoma: 2015 Update. Eur Urol 2015 November 01;68(5):868-879.

[4.] Siegel RL, Miller KD, Jemal A. Cancer statistics, 2016. CA Cancer J Clin 2016 February 01;66(1):7-30.

[5.] Soria F, Marra G, Capoun O et al. Prevention of bladder cancer incidence and recurrence: tobacco use. Curr Opin Urol 2018 January 01;28(1):80-87.

[6.] Polesel J, Bosetti C, di Maso $M$ et al. Duration and intensity of tobacco smoking and the risk of papillary and non-papillary transitional cell carcinoma of the bladder. Cancer Causes Control 2014 September 01;25(9):1151-1158.

[7.]Xu Y, Huo R, Chen X et al. Diabetes mellitus and the risk of bladder cancer: A PRISMA-compliant meta-analysis of cohort studies. Medicine (Baltimore) 2017 November 01;96(46):e8588.

[8.] Tai YS, Chen $\mathrm{CH}$, Huang $\mathrm{CY}$ et al. Diabetes mellitus with poor glycemic control increases bladder cancer recurrence risk in patients with upper urinary tract urothelial carcinoma. Diabetes Metab Res Rev 2015 March 01;31(3):307-314.

[9.] Stocks $T$, Van Hemelrijck $M$, Manjer et al. Blood pressure and risk of cancer incidence and mortality in the Metabolic Syndrome and Cancer Project. Hypertension 2012 April 01;59(4):802810.

[10.] Goossens ME, Zeegers MP, Bazelier MT et al. Risk of bladder cancer in patients with diabetes: a retrospective cohort study. BMJ Open 2015 June 01;5(6):007470.

[11.] Korhonen P, Malila N, Pukkala E et al. The Finnish Cancer Registry as follow-up source of a large trial cohort--accuracy and delay. Acta Oncol 2002;41:381-388.

[12.] Quan H, Li B, Couris CM et al. Updating and validating the Charlson comorbidity index and score for risk adjustment in hospital discharge abstracts using data from 6 countries. Am J Epidemiol. 2011;173:676-82.)

[13.] WHO ATC/DDD index database. Available at: https://www.whocc.no/atc ddd index/ 
Table 1. Population characteristics.

\begin{tabular}{|c|c|c|c|c|c|c|}
\hline & non-users & $\begin{array}{l}\text { ACE- } \\
\text { inhibitors }\end{array}$ & $\begin{array}{l}\text { ATR- } \\
\text { blockers }\end{array}$ & $\begin{array}{l}\text { beta- } \\
\text { blockers }\end{array}$ & $\begin{array}{l}\text { calcium- } \\
\text { channel } \\
\text { blockers }\end{array}$ & diuretics \\
\hline $\begin{array}{l}\text { n of } \\
\text { participants; } \\
\text { (BCa/UTUC) }\end{array}$ & $3578 / 228$ & $5276 / 382$ & $\begin{array}{l}2495 / \\
240\end{array}$ & 7544 / 623 & $3247 / 446$ & 7176 / 516 \\
\hline $\begin{array}{l}\text { men } \\
\text { (BCa/UTUC) }\end{array}$ & $2776 / 148$ & $4123 / 214$ & $\begin{array}{l}1863 / \\
118\end{array}$ & $5788 / 352$ & $2451 / 229$ & $5235 / 243$ \\
\hline $\begin{array}{l}\text { women } \\
\text { (BCa/UTUC) }\end{array}$ & $802 / 80$ & $1153 / 168$ & 632 / 122 & $1753 / 271$ & $796 / 217$ & 1941 / 273 \\
\hline $\begin{array}{l}\text { median follow } \\
\text { up time (IQR), } \\
\text { (BCa/UTUC) }\end{array}$ & $\begin{array}{l}5.2(0-18.9) \\
/ 2.5(0- \\
18.0)\end{array}$ & $\begin{array}{l}5.8(0- \\
18.9) / \\
3(0-18.9)\end{array}$ & $\begin{array}{l}6.5(0- \\
18.9) / \\
3.8(0- \\
18.6)\end{array}$ & $\begin{array}{l}5.8(0- \\
18.9) / \\
2.9(0- \\
18.9)\end{array}$ & $\begin{array}{l}5.7(0- \\
18.9) / \\
3.1(0- \\
18.9)\end{array}$ & $\begin{array}{l}5.4(0-18.9) \\
/ \\
2.6(0-18.9)\end{array}$ \\
\hline $\begin{array}{l}\mathrm{n} \text { of cancer } \\
\text { deaths (\% of } \\
\text { users), } \\
\text { (BCa/UTUC) }\end{array}$ & $\begin{array}{l}1013 \\
(28.3) / 110 \\
(48.2)\end{array}$ & $\begin{array}{c}954(18) / \\
139(36.4)\end{array}$ & $\begin{array}{l}355(14.2) \\
/ 70(29.2)\end{array}$ & $\begin{array}{l}1562 \\
(20.7) / \\
236(37.9)\end{array}$ & $\begin{array}{l}646(19.9) \\
/ 160 \\
(35.9)\end{array}$ & $\begin{array}{l}1678(23.4) \\
/ 229(44.4)\end{array}$ \\
\hline $\begin{array}{l}\text { Age at } \\
\text { diagnosis, } \\
\text { median (IQR), } \\
\text { (BCa/UTUC) }\end{array}$ & $\begin{array}{l}67.5(20- \\
102) / \\
66(29-97)\end{array}$ & $\begin{array}{l}73.2(22- \\
102) / \\
75(44-96)\end{array}$ & $\begin{array}{l}71.1(29- \\
98) / \\
74(44-96)\end{array}$ & $\begin{array}{l}73.6(22- \\
102) / \\
75(44-96)\end{array}$ & $\begin{array}{l}74.2(22- \\
101) / \\
76(44-99)\end{array}$ & $\begin{array}{l}74.8(22- \\
104)\end{array}$ \\
\hline \multicolumn{7}{|l|}{$\begin{array}{l}\text { stage, BCa; } \\
\mathrm{n}(\%)\end{array}$} \\
\hline local & 2071 (57.9) & $\begin{array}{l}3386 \\
(64.2) \\
\end{array}$ & $\begin{array}{l}1627 \\
(65.2) \\
\end{array}$ & $\begin{array}{l}4739 \\
(62.8) \\
\end{array}$ & $\begin{array}{l}2046 \\
(63.0) \\
\end{array}$ & $4354(60.7)$ \\
\hline advanced & $588(16.4)$ & $534(10.1)$ & $249(10.0)$ & 834 (11.1) & $329(10.1)$ & 841 (11.7) \\
\hline unknown & $917(25.6)$ & $\begin{array}{l}1356 \\
(25.7) \\
\end{array}$ & $619(24.8)$ & $\begin{array}{l}1971 \\
(26.1) \\
\end{array}$ & $872(26.9)$ & $1981(27.6)$ \\
\hline \multicolumn{7}{|l|}{$\begin{array}{r}\text { stage, UTUC; } \\
\mathrm{n}(\%)\end{array}$} \\
\hline local & 86 (37.7) & $163(42.7)$ & $116(48.3)$ & $260(41.7)$ & $193(43.3)$ & $209(40.5)$ \\
\hline advanced & $105(46.0)$ & $138(36.1)$ & 79 (32.9) & $224(36.0)$ & $149(33.4)$ & $191(37.0)$ \\
\hline unknown & $37(16.2)$ & $81(21.2)$ & $45(18.8)$ & $139(22.3)$ & $104(23.3)$ & $116(22.5)$ \\
\hline \multicolumn{7}{|l|}{$\begin{array}{l}\text { primary care } \\
\text { of } U C, n(\%)\end{array}$} \\
\hline surgery in $\mathrm{BCa}$ & $1739(48.6)$ & $\begin{array}{l}2717 \\
(51.5) \\
\end{array}$ & $\begin{array}{l}1336 \\
(53.5) \\
\end{array}$ & $\begin{array}{l}3817 \\
(50.6) \\
\end{array}$ & $\begin{array}{l}1622 \\
(50.0) \\
\end{array}$ & $3443(48)$ \\
\hline $\begin{array}{r}\text { radical } \\
\text { cystectomy in } \\
\mathrm{BCa} \\
\end{array}$ & $528(14.8)$ & $506(9.6)$ & $244(9.8)$ & $699(9.3)$ & $283(8.7)$ & $614(8.6)$ \\
\hline
\end{tabular}




\begin{tabular}{|c|c|c|c|c|c|c|}
\hline $\begin{array}{r}\text { other } \\
\text { treatment in } \\
\mathrm{BCa}\end{array}$ & $1030(28.8)$ & $\begin{array}{l}1451 \\
(27.5)\end{array}$ & $623(25.0)$ & $\begin{array}{l}2164 \\
(28.7)\end{array}$ & $952(29.3)$ & 2145 (29.9) \\
\hline $\begin{array}{r}\text { surgery in } \\
\text { UTUC }\end{array}$ & $181(79.4)$ & $288(75.4)$ & $189(78.8)$ & $476(76.4)$ & $341(76.5)$ & $385(74.6)$ \\
\hline $\begin{array}{r}\text { radical nephro- } \\
\text { ureterectomy } \\
\text { in UTUC }\end{array}$ & $138(60.5)$ & $243(63.6)$ & $159(66.3)$ & $394(63.2)$ & $283(63.5)$ & $302(58.5)$ \\
\hline $\begin{array}{r}\text { other } \\
\text { treatment in } \\
\text { UTUC }\end{array}$ & $64(28.0)$ & $81(21.2)$ & $41(17.1)$ & $135(21.7)$ & $97(21.7)$ & $114(22.1)$ \\
\hline $\begin{array}{l}\text { Statin use, } \mathrm{n} \\
\text { (\%)(BCa/UTUC) }\end{array}$ & $\begin{array}{l}535(15) / \\
37(16)\end{array}$ & $\begin{array}{l}2934 \\
(55.6) / \\
234(61.3)\end{array}$ & $\begin{array}{l}1494 \\
(59.9) / \\
150(62.5)\end{array}$ & $\begin{array}{l}3943( \\
52.3) / \\
333(53.5)\end{array}$ & $\begin{array}{l}1699 \\
(52.3) / \\
238(53.4)\end{array}$ & $\begin{array}{l}3211(44.7) \\
/ \\
227(44.0)\end{array}$ \\
\hline $\begin{array}{l}\text { Antidiabetic } \\
\text { medication } \\
\text { use; } n \\
\text { (\%)(BCa/UTUC) }\end{array}$ & $\begin{array}{l}237(6.6) / \\
10(4.4)\end{array}$ & $\begin{array}{l}1810 \\
(34.3) / \\
116(30.4)\end{array}$ & $\begin{array}{l}816(32.7) \\
/ \\
71(29.6)\end{array}$ & $\begin{array}{l}2031 \text { ( } \\
26.9) / \\
135(21.7)\end{array}$ & $\begin{array}{l}933(28.7) \\
/ \\
104(23.3)\end{array}$ & $\begin{array}{l}2025(28.2) \\
/ \\
121(23.4)\end{array}$ \\
\hline $\begin{array}{l}\text { radiotherapy } \\
\text { (n; no } \\
\text { information) }\end{array}$ & $444(835)$ & 566 (1161) & $230(560)$ & 867 (1641) & $362(711)$ & 890 (1671) \\
\hline $\begin{array}{l}\text { chemotherapy } \\
\text { (n; no } \\
\text { information) }\end{array}$ & 746 (777) & $\begin{array}{l}1089 \\
(1054)\end{array}$ & $521(509)$ & $\begin{array}{l}1511 \\
(1494)\end{array}$ & $624(649)$ & $1417(1512)$ \\
\hline
\end{tabular}

$\mathrm{BCa}=$ Bladder cancer, UTUC= Upper tract urothelial carcinoma, UC=urothelial cancer, IQR=interquartile range. 
Table 2. Risk of urothelial cancer death by antihypertensive drug use before diagnosis of UC.

\begin{tabular}{|c|c|c|c|c|c|c|}
\hline & & \multicolumn{2}{|c|}{ Risk of BCa death } & & \multicolumn{2}{|c|}{ Risk of UTUC death } \\
\hline Drug group & $\begin{array}{c}\mathrm{n} \text { of } \\
\text { users/BCa } \\
\text { deaths }\end{array}$ & $\begin{array}{c}\mathrm{HR}(95 \% \\
\mathrm{Cl})_{\text {age- }} \\
\text { adjusted }\end{array}$ & $\begin{array}{c}\mathrm{HR}(95 \% \\
\mathrm{Cl})_{\text {multiavariable }} \\
\text { adjusted* }\end{array}$ & $\begin{array}{c}\mathrm{n} \text { of } \\
\text { users/UTUC } \\
\text { deaths }\end{array}$ & $\begin{array}{c}\mathrm{HR}(95 \% \mathrm{Cl})_{\text {age- }} \\
\text { adjusted }\end{array}$ & $\begin{array}{c}\mathrm{HR}(95 \% \\
\mathrm{Cl})_{\text {multiavariable }} \\
\text { adjusted* } \\
\end{array}$ \\
\hline $\begin{array}{c}\text { ACE } \\
\text { inhibitors }\end{array}$ & $3450 / 751$ & $\begin{array}{l}0.89 \\
(0.81- \\
0.97) \\
\end{array}$ & $\begin{array}{l}1.03(0.94- \\
1.13)\end{array}$ & $267 / 123$ & $1.14(0.90-1.43)$ & $\begin{array}{l}1.48(1.00- \\
2.21)\end{array}$ \\
\hline $\begin{array}{c}\text { ATR- } \\
\text { blockers }\end{array}$ & $1409 / 258$ & $\begin{array}{l}0.76 \\
(0.67- \\
0.87) \\
\end{array}$ & $\begin{array}{l}0.80(0.70- \\
0.92)\end{array}$ & $144 / 52$ & $0.78(0.58-1.06)$ & $\begin{array}{l}0.87(0.54- \\
1.39)\end{array}$ \\
\hline $\begin{array}{c}\text { Average } \\
\text { yearly dose } \\
\text { of ATR- } \\
\text { blocker } \\
\text { (DDDs/year) }\end{array}$ & & & & & & \\
\hline $0-245$ & $475 / 111$ & $\begin{array}{l}0.97 \\
(0.80- \\
1.18) \\
\end{array}$ & $\begin{array}{l}0.92(0.76- \\
1.12)\end{array}$ & $49 / 20$ & $1.02(0.65-1.62)$ & $\begin{array}{l}1.36(0.63- \\
2.95)\end{array}$ \\
\hline $245-392$ & $465 / 83$ & $\begin{array}{l}0.71 \\
(0.57- \\
0.89) \\
\end{array}$ & $\begin{array}{l}0.80(0.64- \\
1.00)\end{array}$ & $47 / 16$ & $0.67(0.40-1.11)$ & $\begin{array}{l}1.13(0.50- \\
2.58)\end{array}$ \\
\hline $392 \rightarrow$ & 467 / 63 & $\begin{array}{l}0.58 \\
(0.45- \\
0.75) \\
\end{array}$ & $\begin{array}{l}0.65(0.50- \\
0.84)\end{array}$ & $48 / 16$ & $0.69(0.41-1.15)$ & $\begin{array}{l}0.63(0.33- \\
1.19)\end{array}$ \\
\hline $\begin{array}{c}\text { Beta- } \\
\text { blockers }\end{array}$ & $5327 / 1211$ & $\begin{array}{l}0.85 \\
(0.78- \\
0.91) \\
\end{array}$ & $\begin{array}{l}1.03(0.95- \\
1.12)\end{array}$ & 448 / 189 & $0.91(0.73-1.12)$ & $\begin{array}{l}1.15(0.76- \\
1.75)\end{array}$ \\
\hline $\begin{array}{l}\text { Calcium- } \\
\text { channel } \\
\text { blockers }\end{array}$ & $754 / 180$ & $\begin{array}{l}0.87 \\
(0.79- \\
0.96)\end{array}$ & $\begin{array}{l}0.98(0.88- \\
1.08)\end{array}$ & $281 / 116$ & $0.86(0.68-1.09)$ & $\begin{array}{l}0.77(0.52- \\
1.15)\end{array}$ \\
\hline Diuretics & $4426 / 1121$ & $\begin{array}{l}1.20 \\
(1.10- \\
1.31)\end{array}$ & $\begin{array}{l}1.13(1.04- \\
1.24)\end{array}$ & $311 / 149$ & $1.30(1.04-1.63)$ & $\begin{array}{l}1.20(0.78- \\
1.83)\end{array}$ \\
\hline
\end{tabular}

*= calculated cox regression model with adjustments of age, radical surgery, tumor extent, $\mathrm{CCl}$, year of diagnosis, statin, NSAID, aspirin and antidiabetic medication use, kidney failure, COPD and cytostatic drugs. $\mathrm{UC}=$ Urothelial cancer, $\mathrm{BCa}=$ Bladder cancer, $\mathrm{UTUC}=$ Upper tract urothelial carcinoma, $\mathrm{DDD}=$ Defined Daily Dose 
Table 3. Risk of bladder cancer death by cumulative amount, duration and average yearly dose of ATRblocker use after diagnosis.

\begin{tabular}{|c|c|c|c|}
\hline $\begin{array}{l}\text { Amount of use } \\
\text { (DDDs) }\end{array}$ & $\begin{array}{l}n \text { of users/BCa } \\
\text { deaths }\end{array}$ & $\begin{array}{l}\text { Riski of BCa death } \\
\text { HR }(95 \% \mathrm{Cl}) \text { age- } \\
\text { adjusted }\end{array}$ & $\begin{array}{l}\text { Risk of BCa death } \\
\text { HR }(95 \% \mathrm{Cl}) \\
\text { multiavariable adjusted* }\end{array}$ \\
\hline $0-490$ & 641 / 148 & $0.82(0.70-0.97)$ & $0.90(0.76-1.06)$ \\
\hline $490-1764$ & $641 / 91$ & $0.59(0.47-0.73)$ & $0.73(0.59-0.91)$ \\
\hline $1764 \rightarrow$ & $657 / 23$ & $0.51(0.33-0.78)$ & $0.60(0.39-0.91)$ \\
\hline $\begin{array}{l}\text { Duration of use } \\
\text { (years) }\end{array}$ & $\begin{array}{l}n \text { of users/BCa } \\
\text { deaths }\end{array}$ & $\begin{array}{l}\text { Riski of } \mathrm{BCa} \text { death } \\
\mathrm{HR}(95 \% \mathrm{Cl}) \text { age- } \\
\text { adjusted }\end{array}$ & $\begin{array}{l}\text { Risk of } \mathrm{BCa} \text { death } \\
\mathrm{HR}(95 \% \mathrm{Cl})\end{array}$ \\
\hline $0-2$ & $601 / 153$ & $0.69(0.60-0.80)$ & $0.80(0.69-0.93)$ \\
\hline $2-4$ & $245 / 25$ & $0.71(0.51-1.00)$ & $0.85(0.60-1.18)$ \\
\hline $4 \rightarrow$ & $566 / 24$ & $0.74(0.49-1.3)$ & $0.80(0.52-1.22)$ \\
\hline $\begin{array}{l}\text { Average yearly } \\
\text { dose (DDDs/year) }\end{array}$ & $\begin{array}{l}\mathrm{n} \text { of users/BCa } \\
\text { deaths }\end{array}$ & $\begin{array}{l}\text { Riski of } \mathrm{BCa} \text { death } \\
\mathrm{HR}(95 \% \mathrm{Cl}) \text { age- } \\
\text { adjusted }\end{array}$ & $\begin{array}{l}\text { Risk of } \mathrm{BCa} \text { death } \\
\mathrm{HR}(95 \% \mathrm{Cl})\end{array}$ \\
\hline $0-259$ & $634 / 135$ & $1.04(0.87-1.24)$ & $1.04(0.87-1.24)$ \\
\hline $259-504$ & $630 / 98$ & $0.67(0.54-0.82)$ & $0.79(0.64-0.97)$ \\
\hline $504 \rightarrow$ & $632 / 34$ & $0.35(0.26-0.48)$ & $0.48(0.35-0.65)$ \\
\hline
\end{tabular}

*= calculated cox regression model with adjustments of age, radical surgery, tumor extent, $\mathrm{CCl}$, year of diagnosis, statin, NSAID, aspirin and antidiabetic medication use, kidney failure, COPD and cytostatic drugs. UC= Urothelial cancer, BCa= Bladder cancer, UTUC= Upper tract urothelial carcinoma, DDD= Defined Daily Dose 
Table 4. Risk of UC death by antihypertensive drug use after UC diagnosis.

\begin{tabular}{|c|c|c|c|c|c|c|}
\hline & & \multicolumn{2}{|c|}{ Risk of BCa death } & \multicolumn{3}{|c|}{ Lag-time } \\
\hline Drug group & $\begin{array}{c}\text { n of users/BCa } \\
\text { deaths }\end{array}$ & $\begin{array}{c}\mathrm{HR}(95 \% \\
\mathrm{Cl})_{\text {age-adjusted }}\end{array}$ & $\begin{array}{c}\mathrm{HR}(95 \% \\
\mathrm{Cl})_{\text {multiavariable }} \\
\text { adjusted }\left({ }^{*}\right)\end{array}$ & $1 \mathrm{yr}$ & $3 y r s$ & $5 y r s$ \\
\hline ACE inhibitors & $377 / 19$ & $\begin{array}{l}0.80(0.73- \\
0.88)\end{array}$ & $\begin{array}{l}0.99(0.90- \\
1.08)\end{array}$ & $\begin{array}{c}1.06 \\
(0.96- \\
1.17) \\
\end{array}$ & $\begin{array}{l}0.99 \\
(0.88- \\
1.00) \\
\end{array}$ & $\begin{array}{l}0.99 \\
(0.88- \\
1.10) \\
\end{array}$ \\
\hline ATR blockers & $177 / 4$ & $\begin{array}{c}0.70(0.61- \\
0.79)\end{array}$ & $\begin{array}{l}0.81(0.71- \\
0.92)\end{array}$ & $\begin{array}{c}0.82 \\
(0.71- \\
0.93)\end{array}$ & $\begin{array}{l}0.72 \\
(0.61- \\
0.85)\end{array}$ & $\begin{array}{l}0.72 \\
(0.61- \\
0.85)\end{array}$ \\
\hline Beta-blockers & $500 / 20$ & $\begin{array}{l}0.89(0.82- \\
0.96)\end{array}$ & $\begin{array}{l}1.05(0.97- \\
1.13)\end{array}$ & $\begin{array}{c}1.09 \\
(1.01- \\
1.18)\end{array}$ & $\begin{array}{l}1.08 \\
(0.99- \\
1.19)\end{array}$ & $\begin{array}{l}1.08 \\
(1.00- \\
1.19) \\
\end{array}$ \\
\hline $\begin{array}{c}\text { Calcium-channel } \\
\text { blockers }\end{array}$ & $127 / 3$ & $\begin{array}{l}0.85(0.76- \\
0.95)\end{array}$ & $\begin{array}{l}0.95(0.85- \\
1.06)\end{array}$ & $\begin{array}{c}0.93 \\
(0.83- \\
1.05)\end{array}$ & $\begin{array}{l}0.92 \\
(0.81- \\
1.05)\end{array}$ & $\begin{array}{l}0.92 \\
(0.81- \\
1.05)\end{array}$ \\
\hline \multirow[t]{2}{*}{ Diuretics } & $490 / 30$ & $\begin{array}{l}1.53(1.41- \\
1.66)\end{array}$ & $\begin{array}{l}1.42(1.31- \\
1.54)\end{array}$ & $\begin{array}{c}1.24 \\
(1.14- \\
1.35)\end{array}$ & $\begin{array}{l}1.21 \\
(1.10- \\
1.34)\end{array}$ & $\begin{array}{l}1.21 \\
(1.10- \\
1.34)\end{array}$ \\
\hline & & \multicolumn{2}{|c|}{ Risk of UTUC death } & \multicolumn{3}{|c|}{ Lag-time } \\
\hline Drug group & $\begin{array}{l}\mathrm{n} \text { of users/BCa } \\
\text { deaths }\end{array}$ & $\begin{array}{l}\mathrm{HR}(95 \% \\
\mathrm{Cl})_{\text {age-adjusted }}\end{array}$ & $\begin{array}{l}\mathrm{HR}(95 \% \\
\mathrm{Cl})_{\text {multiavariable }} \\
\text { adjusted }\left({ }^{*}\right)\end{array}$ & $1 \mathrm{yr}$ & $3 y r s$ & $5 y r s$ \\
\hline ACE inhibitors & $179 / 74$ & $\begin{array}{l}0.87(0.67- \\
1.12)\end{array}$ & $\begin{array}{l}1.20(0.79- \\
1.85)\end{array}$ & $\begin{array}{c}1.23 \\
(0.81- \\
1.87)\end{array}$ & $\begin{array}{l}1.39 \\
(0.92- \\
2.12)\end{array}$ & $\begin{array}{l}1.45 \\
(0.95- \\
2.11)\end{array}$ \\
\hline ATR blockers & $130 / 49$ & $\begin{array}{l}0.81(0.60- \\
1.11)\end{array}$ & $\begin{array}{l}1.03(0.65- \\
1.65)\end{array}$ & $\begin{array}{c}1.07 \\
(0.66- \\
1.74)\end{array}$ & $\begin{array}{l}1.08 \\
(0.62- \\
1.87)\end{array}$ & $\begin{array}{l}0.88 \\
(0.41- \\
1.88)\end{array}$ \\
\hline Beta-blockers & $410 / 178$ & $\begin{array}{l}0.96(0.78- \\
1.18)\end{array}$ & $\begin{array}{l}1.06(0.70- \\
1.59)\end{array}$ & $\begin{array}{c}1.06 \\
(0.71- \\
1.59)\end{array}$ & $\begin{array}{l}1.02 \\
(0.70- \\
1.49)\end{array}$ & $\begin{array}{l}1.09 \\
(0.74- \\
1.59)\end{array}$ \\
\hline $\begin{array}{c}\text { Calcium-channel } \\
\text { blockers }\end{array}$ & $238 / 104$ & $\begin{array}{l}1.00(0.80- \\
1.25)\end{array}$ & $\begin{array}{l}0.93(0.62- \\
1.40)\end{array}$ & $\begin{array}{c}0.93 \\
(0.62- \\
1.40)\end{array}$ & $\begin{array}{l}0.90 \\
(0.59- \\
1.39)\end{array}$ & $\begin{array}{l}1.05 \\
(0.66- \\
1.68)\end{array}$ \\
\hline Diuretics & $285 / 146$ & $\begin{array}{l}1.46 \text { (1.17- } \\
1.83)\end{array}$ & $\begin{array}{l}1.47 \text { (0.95- } \\
2.28)\end{array}$ & $\begin{array}{c}1.28 \\
(0.82- \\
2.02)\end{array}$ & $\begin{array}{l}1.44 \\
(0.91- \\
2.29)\end{array}$ & $\begin{array}{l}1.32 \\
(0.81- \\
2.15)\end{array}$ \\
\hline
\end{tabular}

*= calculated cox regression model with adjustments of age, radical surgery , tumor extent, $\mathrm{CCl}$, year of diagnosis, statin, NSAID, aspirin and antidiabetic medication use, kidney failure, COPD and cytostatic drugs. UC= Urothelial cancer, $\mathrm{BCa}=$ Bladder cancer, UTUC= Upper tract urothelial carcinoma, DDD= Defined Daily Dose 
Table 5. Risk of BCa death by cumulative amount, duration and average yearly dose of calcium-channel blocker use after diagnosis.

\begin{tabular}{|l|l|l|l|}
\hline $\begin{array}{l}\text { Amount of use } \\
\text { (DDDs) }\end{array}$ & $\begin{array}{l}\text { n of users/BCa } \\
\text { deaths }\end{array}$ & $\begin{array}{l}\text { Riski of BCa death } \\
\text { HR }(95 \% \mathrm{Cl}) \text { age- } \\
\text { adjusted }\end{array}$ & $\begin{array}{l}\text { Risk of BCa death } \\
\mathrm{HR}(95 \% \mathrm{Cl}) \\
\text { multivariable adjusted* }\end{array}$ \\
\hline $0-333$ & $690 / 210$ & $1.04(0.90-1.21)$ & $1.14(0.99-1.33)$ \\
\hline $333-1200$ & $687 / 127$ & $0.67(0.55-0.82)$ & $0.82(0.67-1.00)$ \\
\hline $1200 \rightarrow$ & $691 / 37$ & $0.48(0.28-0.81)$ & $0.56(0.33-0.94)$ \\
\hline \multicolumn{4}{|l|}{} \\
\hline $\begin{array}{l}\text { Duration of use } \\
\text { (years) }\end{array}$ & $\begin{array}{l}\text { n of users/BCa } \\
\text { deaths }\end{array}$ & $\begin{array}{l}\text { Riski of BCa death } \\
\text { HR (95\%Cl) age- } \\
\text { adjusted }\end{array}$ & $\begin{array}{l}\text { Risk of BCa death } \\
\text { HR (95\% CI) }\end{array}$ \\
\hline $0-1$ & $686 / 207$ & $0.83(0.72-0.95)$ & $0.93(0.81-1.07)$ \\
\hline $1-4$ & $814 / 146$ & $0.93(0.78-1.12)$ & $1.03(0.86-1.23)$ \\
\hline $4 \rightarrow$ & $537 / 21$ & $0.69(0.45-1.08)$ & $0.73(0.47-1.13)$ \\
\hline \multicolumn{5}{|l|}{$\begin{array}{l}\text { Riski of BCa death } \\
\text { HR (95\%Cl) age- } \\
\text { adjusted }\end{array}$} & $\begin{array}{l}\text { Risk of BCa death } \\
\text { HR (95\% Cl) }\end{array}$ \\
\hline dose (DDDs/year) & $\begin{array}{l}\mathrm{n} \text { of users/BCa } \\
\text { deaths }\end{array}$ & $1.20(1.02-1.41)$ & $1.26(1.06-1.48)$ \\
\hline $0-196$ & $667 / 155$ & $0.69(0.56-0.85)$ & $0.91(0.73-1.13)$ \\
\hline $196-367$ & $624 / 113$ & $0.61(0.48-0.78)$ & $0.67(0.52-0.86)$ \\
\hline $367 \rightarrow$ & $678 / 78$ &
\end{tabular}

*= calculated cox regression model with adjustments of age, radical surgery, tumor extent, $\mathrm{CCl}$, year of diagnosis, statin, NSAID, aspirin and antidiabetic medication use, kidney failure, COPD and cytostatic drugs. UC= Urothelial cancer, BCa= Bladder cancer, UTUC= Upper tract urothelial carcinoma, DDD= Defined Daily Dose 
Table 6. Risk of UC death before and after diagnosis by antihypertensive drug use. Separated analyses by gender (men/women).

\begin{tabular}{|c|c|c|c|c|c|c|c|c|}
\hline \multirow{3}{*}{$\begin{array}{l}\text { Drug } \\
\text { group } \\
\text { used }\end{array}$} & \multicolumn{4}{|c|}{ Risk of BCa death in men } & \multicolumn{4}{|c|}{ Risk of BCa death in women } \\
\hline & \multicolumn{2}{|c|}{$\begin{array}{l}\text { Before } \mathrm{BCa} \\
\text { diagnosis }\end{array}$} & \multicolumn{2}{|c|}{ After $\mathrm{BCa}$ diagnosis } & \multicolumn{2}{|c|}{ Before $\mathrm{BCa}$ diagnosis } & \multicolumn{2}{|c|}{ After BCa diagnosis } \\
\hline & $\begin{array}{l}\mathrm{HR} \\
(95 \% \\
\mathrm{Cl})_{\text {age- }} \\
\text { adjusted }\end{array}$ & $\begin{array}{l}\mathrm{HR}(95 \% \\
\mathrm{Cl})_{\text {multiavariable }} \\
\text { adjusted* }\end{array}$ & $\begin{array}{l}\mathrm{HR} \\
(95 \% \\
\mathrm{Cl})_{\text {age- }} \\
\text { adjusted }\end{array}$ & $\begin{array}{l}\mathrm{HR}(95 \% \\
\mathrm{Cl})_{\text {multiavariable }} \\
\text { adjusted* }\end{array}$ & $\begin{array}{l}\mathrm{HR}(95 \% \\
\mathrm{Cl})_{\text {age- }} \\
\text { adjusted }\end{array}$ & $\begin{array}{l}\text { HR (95\% } \\
\mathrm{Cl})_{\text {multiavariable }} \\
\text { adjusted* }\end{array}$ & $\begin{array}{l}\mathrm{HR}(95 \% \\
\mathrm{Cl})_{\text {age- }} \\
\text { adjusted }\end{array}$ & $\begin{array}{l}\text { HR (95\% } \\
\mathrm{Cl})_{\text {multiavariable }} \\
\text { adjusted* }\end{array}$ \\
\hline $\begin{array}{l}\text { ACE } \\
\text { inhibitors }\end{array}$ & $\begin{array}{l}0.94 \\
(0.84- \\
1.05) \\
\end{array}$ & $\begin{array}{l}1.13(1.01- \\
1.27)\end{array}$ & \begin{tabular}{|l|}
0.81 \\
$(0.72-$ \\
$0.90)$ \\
\end{tabular} & ) & $\begin{array}{l}0.85 \\
(0.71- \\
1.00) \\
\end{array}$ & $\begin{array}{l}0.87(0.74- \\
1.04)\end{array}$ & $\begin{array}{l}1 \\
67- \\
6) \\
\end{array}$ & $\begin{array}{l}0.92(0.77- \\
1.10)\end{array}$ \\
\hline $\begin{array}{l}\text { ATR } \\
\text { blockers }\end{array}$ & $\begin{array}{l}0.76 \\
(0.65- \\
0.90)\end{array}$ & $\begin{array}{l}0.84(0.71- \\
1.00)\end{array}$ & $\begin{array}{l}0.67 \\
(0.57- \\
0.78)\end{array}$ & $\begin{array}{l}0.79(0.67- \\
0.93)\end{array}$ & $\begin{array}{l}0.76 \\
(0.60- \\
0.95)\end{array}$ & $\begin{array}{l}0.76(0.60- \\
0.96)\end{array}$ & $\begin{array}{l}0.74 \\
(0.59- \\
0.93)\end{array}$ & $\begin{array}{l}0.82(0.66- \\
1.04)\end{array}$ \\
\hline $\begin{array}{l}\text { Beta- } \\
\text { blockers }\end{array}$ & $\begin{array}{l}0.91 \\
(0.83- \\
1.00)\end{array}$ & $\begin{array}{l}1.18(1.07- \\
1.30)\end{array}$ & $\begin{array}{l}0.93 \\
(0.85- \\
1.02) \\
\end{array}$ & $\begin{array}{l}1.14(1.04- \\
1.25)\end{array}$ & $\begin{array}{l}0.74 \\
(0.64- \\
0.85) \\
\end{array}$ & $\begin{array}{l}0.80(0.69- \\
0.92)\end{array}$ & $\begin{array}{l}1 \\
71- \\
3)\end{array}$ & $\begin{array}{l}0.89(0.78- \\
1.03)\end{array}$ \\
\hline $\begin{array}{l}\text { Calcium- } \\
\text { channel } \\
\text { blockers }\end{array}$ & $\begin{array}{l}0.82 \\
(0.73- \\
0.93) \\
\end{array}$ & $\begin{array}{l}0.96(0.85- \\
1.09)\end{array}$ & $\begin{array}{l}0.81 \\
(0.71- \\
0.93) \\
\end{array}$ & (0.80- & $\begin{array}{l}0.98 \\
(0.83- \\
1.16) \\
\end{array}$ & (0.85- & $\begin{array}{l}0.93 \\
(0.77- \\
1.12) \\
\end{array}$ & $\begin{array}{l}5(0.86- \\
7)\end{array}$ \\
\hline \multirow[t]{2}{*}{ Diuretics } & $\begin{array}{l}1.14 \\
(1.02- \\
1.27)\end{array}$ & $\begin{array}{l}1.05(0.94- \\
1.17)\end{array}$ & $\begin{array}{l}1.67 \\
(1.51- \\
1.84)\end{array}$ & $\begin{array}{l}1.54(1.40- \\
1.71)\end{array}$ & $\begin{array}{l}1.19 \\
(1.03- \\
1.37)\end{array}$ & )$^{(1.03-}$ & $\begin{array}{l}1.21 \\
(1.05- \\
1.39)\end{array}$ & $\begin{array}{l}1.18(1.03- \\
1.36)\end{array}$ \\
\hline & \multicolumn{4}{|c|}{ Risk of UTUC death in men } & \multicolumn{4}{|c|}{ Risk of UTUC death in women } \\
\hline \multirow{2}{*}{$\begin{array}{l}\text { Drug } \\
\text { group } \\
\text { used }\end{array}$} & \multicolumn{2}{|c|}{$\begin{array}{l}\text { Before UTUC } \\
\text { diagnosis }\end{array}$} & \multicolumn{2}{|c|}{$\begin{array}{l}\text { After UTUC } \\
\text { diagnosis }\end{array}$} & \multicolumn{2}{|c|}{$\begin{array}{l}\text { Before UTUC } \\
\text { diagnosis }\end{array}$} & \multicolumn{2}{|c|}{ After UTUC diagnosis } \\
\hline & $\begin{array}{l}\mathrm{HR} \\
(95 \% \\
\mathrm{Cl})_{\text {age- }} \\
\text { adjusted }\end{array}$ & $\begin{array}{l}\mathrm{HR}(95 \% \\
\mathrm{Cl})_{\text {multiavariable }} \\
\text { adjusted* }\end{array}$ & \begin{tabular}{|l} 
HR \\
$(95 \%$ \\
$\mathrm{Cl})_{\text {age- }}$ \\
adjusted \\
\end{tabular} & $\begin{array}{l}\mathrm{HR}(95 \% \\
\mathrm{Cl})_{\text {multiavariable }} \\
\text { adjusted* }^{*}\end{array}$ & $\begin{array}{l}\mathrm{HR}(95 \% \\
\mathrm{Cl})_{\text {age- }} \\
\text { adjusted }\end{array}$ & $\begin{array}{l}\mathrm{HR}(95 \% \\
\mathrm{Cl})_{\text {multiavariable }} \\
\text { adjusted* }\end{array}$ & $\begin{array}{l}\mathrm{HR}(95 \% \\
\mathrm{Cl})_{\text {age- }} \\
\text { adjusted }\end{array}$ & $\begin{array}{l}\mathrm{HR}(95 \% \\
\mathrm{Cl})_{\text {multiavariable }} \\
\text { adjusted* }\end{array}$ \\
\hline $\begin{array}{l}\text { ACE } \\
\text { inhibitors }\end{array}$ & $\begin{array}{l}1.14 \\
(0.83- \\
1.57)\end{array}$ & $\begin{array}{l}1.66(0.90- \\
3.06)\end{array}$ & $\begin{array}{l}0.86 \\
(0.60- \\
1.22) \\
\end{array}$ & $(0.79-$ & $\begin{array}{l}6 \\
83- \\
2)\end{array}$ & $\begin{array}{l}1.55(0.82- \\
2.93)\end{array}$ & $\begin{array}{l}6 \\
8- \\
7)\end{array}$ & $\begin{array}{l}1.06(0.56- \\
1.99)\end{array}$ \\
\hline $\begin{array}{l}\text { ATR } \\
\text { blockers }\end{array}$ & $\begin{array}{l}0.94 \\
(0.61- \\
1.45) \\
\end{array}$ & $\begin{array}{l}0.83(0.40- \\
1.72)\end{array}$ & \begin{tabular}{|l|}
0.78 \\
$(0.50-$ \\
$1.24)$ \\
\end{tabular} & $\begin{array}{l}0.91(0.43- \\
1.93)\end{array}$ & $\begin{array}{l}0.69 \\
(0.45- \\
1.06)\end{array}$ & $\begin{array}{l}0.92(0.46- \\
1.84)\end{array}$ & $\begin{array}{l}0.85 \\
(0.56- \\
1.29)\end{array}$ & $\begin{array}{l}1.30(0.67- \\
2.54)\end{array}$ \\
\hline $\begin{array}{l}\text { Beta- } \\
\text { blockers }\end{array}$ & $\begin{array}{l}0.69 \\
(0.52- \\
0.92) \\
\end{array}$ & $\begin{array}{l}1.98(1.05- \\
3.73)\end{array}$ & \begin{tabular}{|l|}
0.82 \\
$(0.62-$ \\
$1.09)$ \\
\end{tabular} & $\begin{array}{l}1.14(0.63- \\
2.06)\end{array}$ & $\begin{array}{l}1.25 \\
(0.91- \\
1.73) \\
\end{array}$ & $\begin{array}{l}0.75(0.39- \\
1.45)\end{array}$ & $\begin{array}{l}4 \\
\text { 33- } \\
6)\end{array}$ & $\begin{array}{l}1.19(0.64- \\
2.24)\end{array}$ \\
\hline $\begin{array}{l}\text { Calcium- } \\
\text { channel } \\
\text { blockers }\end{array}$ & $\begin{array}{l}0.91 \\
(0.65- \\
1.26) \\
\end{array}$ & $\begin{array}{l}0.65(0.35- \\
1.21)\end{array}$ & \begin{tabular}{|l|}
1.05 \\
$(0.77-$ \\
$1.45)$ \\
\end{tabular} & $\begin{array}{l}0.74(0.40- \\
1.38)\end{array}$ & $\begin{array}{l}0.75 \\
(0.53- \\
1.06) \\
\end{array}$ & $\begin{array}{l}1.01(0.55- \\
1.85)\end{array}$ & $\begin{array}{l}0.97 \\
(0.70- \\
1.34)\end{array}$ & $\begin{array}{l}1.12(0.62- \\
2.04)\end{array}$ \\
\hline Diuretics & $\begin{array}{l}1.51 \\
(1.10- \\
2.08) \\
\end{array}$ & $\begin{array}{l}1.78(0.96- \\
3.30)\end{array}$ & \begin{tabular}{|l|}
1.59 \\
$(1.17-$ \\
$2.18)$ \\
\end{tabular} & $\begin{array}{l}1.51(0.75- \\
3.04)\end{array}$ & $\begin{array}{l}1.14 \\
(0.82- \\
1.59) \\
\end{array}$ & $\begin{array}{l}0.93(0.49- \\
1.76)\end{array}$ & $\begin{array}{l}1.36 \\
(0.98- \\
1.90) \\
\end{array}$ & $\begin{array}{l}1.23(0.64- \\
2.34)\end{array}$ \\
\hline
\end{tabular}

*= calculated cox regression model with adjustments of age, radical surgery, tumor extent, $\mathrm{CCl}$, year of diagnosis, statin, NSAID, aspirin and antidiabetic medication use, kidney failure, COPD and cytostatic drugs. UC= Urothelial cancer, $\mathrm{BCa}=\mathrm{Bladder}$ cancer, $\mathrm{UTUC}=$ Upper tract urothelial carcinoma, $\mathrm{DDD}=$ Defined Daily Dose 


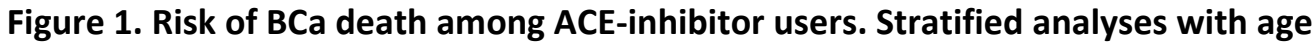
at diagnosis, tumor extent, $\mathrm{CCl}$, statin use and year of $\mathrm{BCa}$ diagnosis.

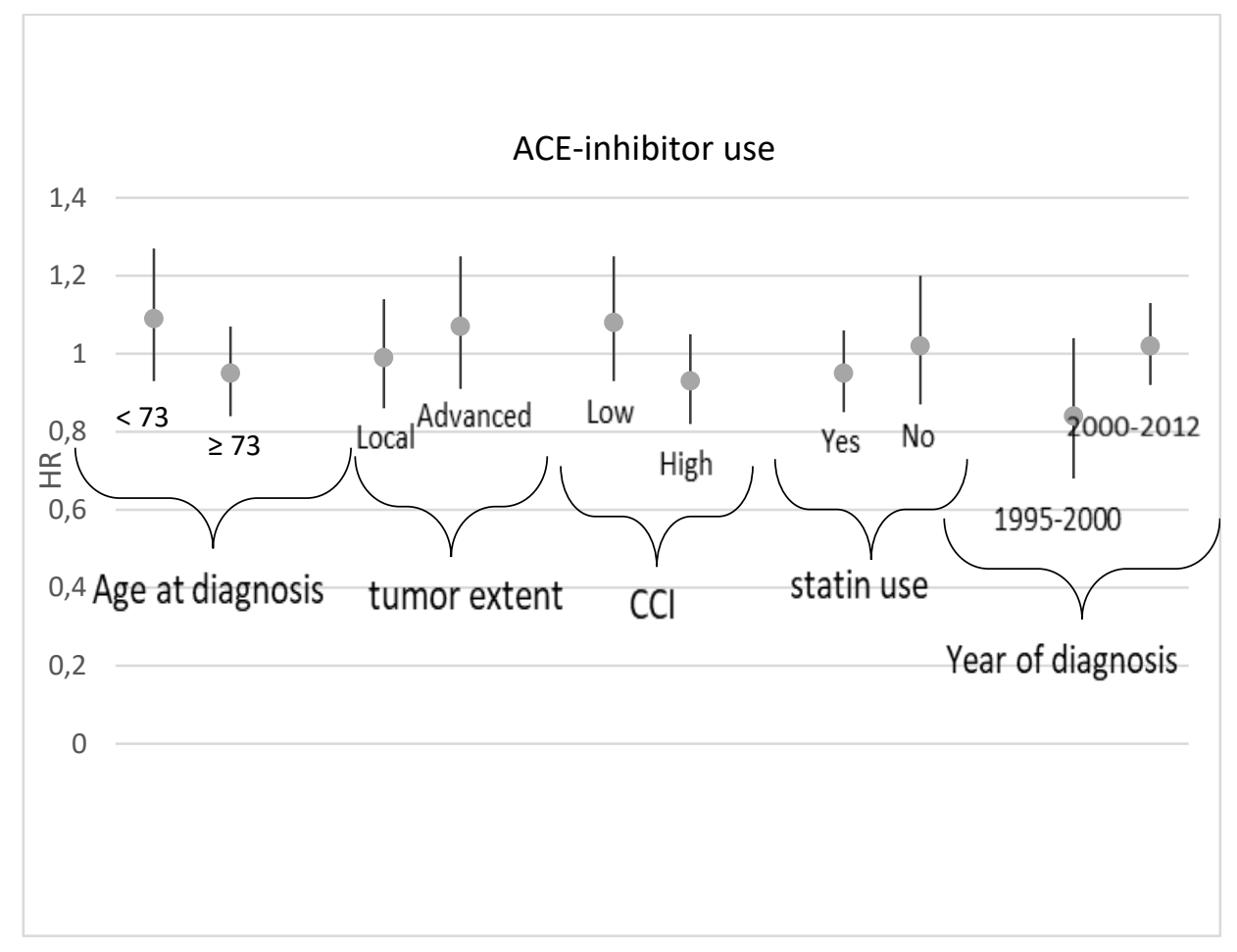

Figure 2. Risk of BCa death among ATR-blocker users. Stratified analyses with age at diagnosis, tumor extent, $\mathrm{CCl}$, statin use and year of $\mathrm{BCa}$ diagnosis.

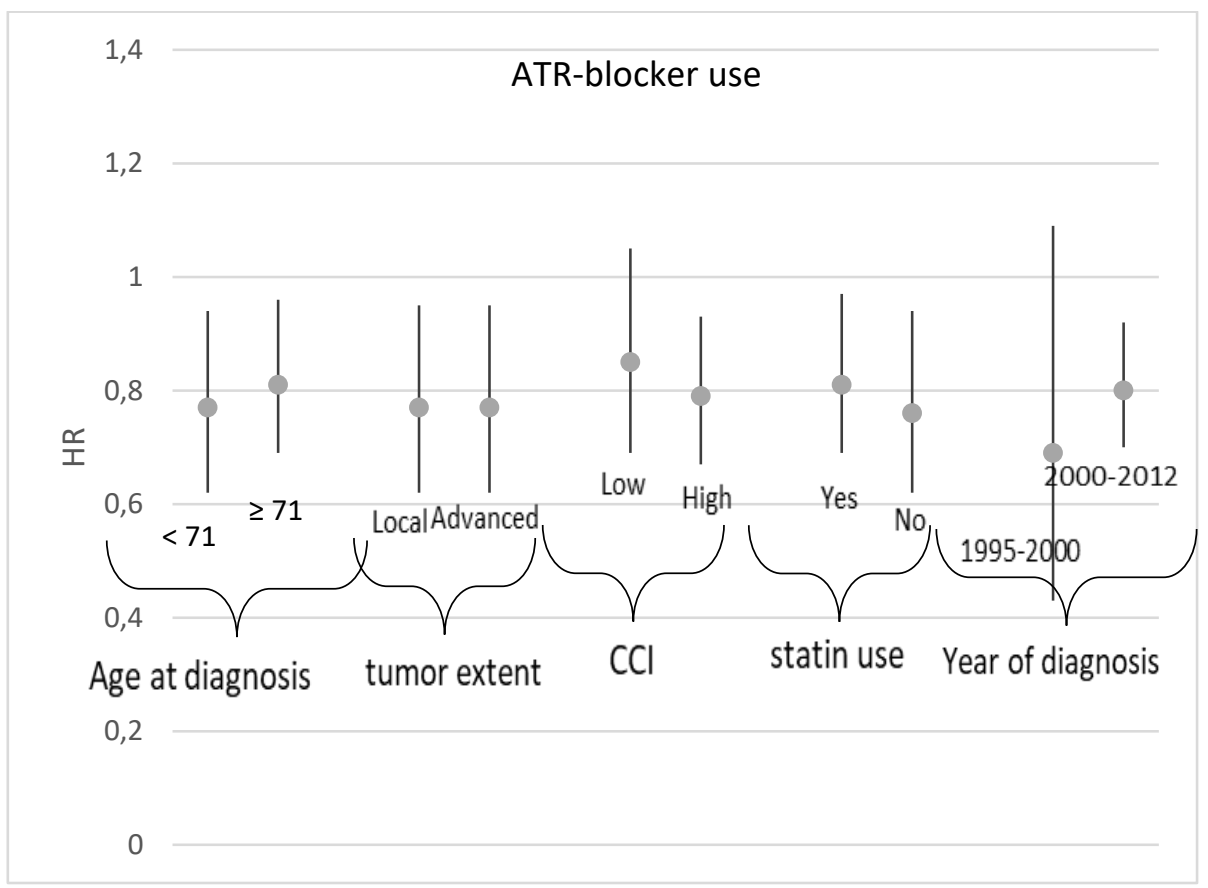


Figure 3. Risk of BCa death among beta-blocker users. Stratified analyses with age at diagnosis, tumor extent, $\mathrm{CCl}$, statin use and year of $\mathrm{BCa}$ diagnosis.

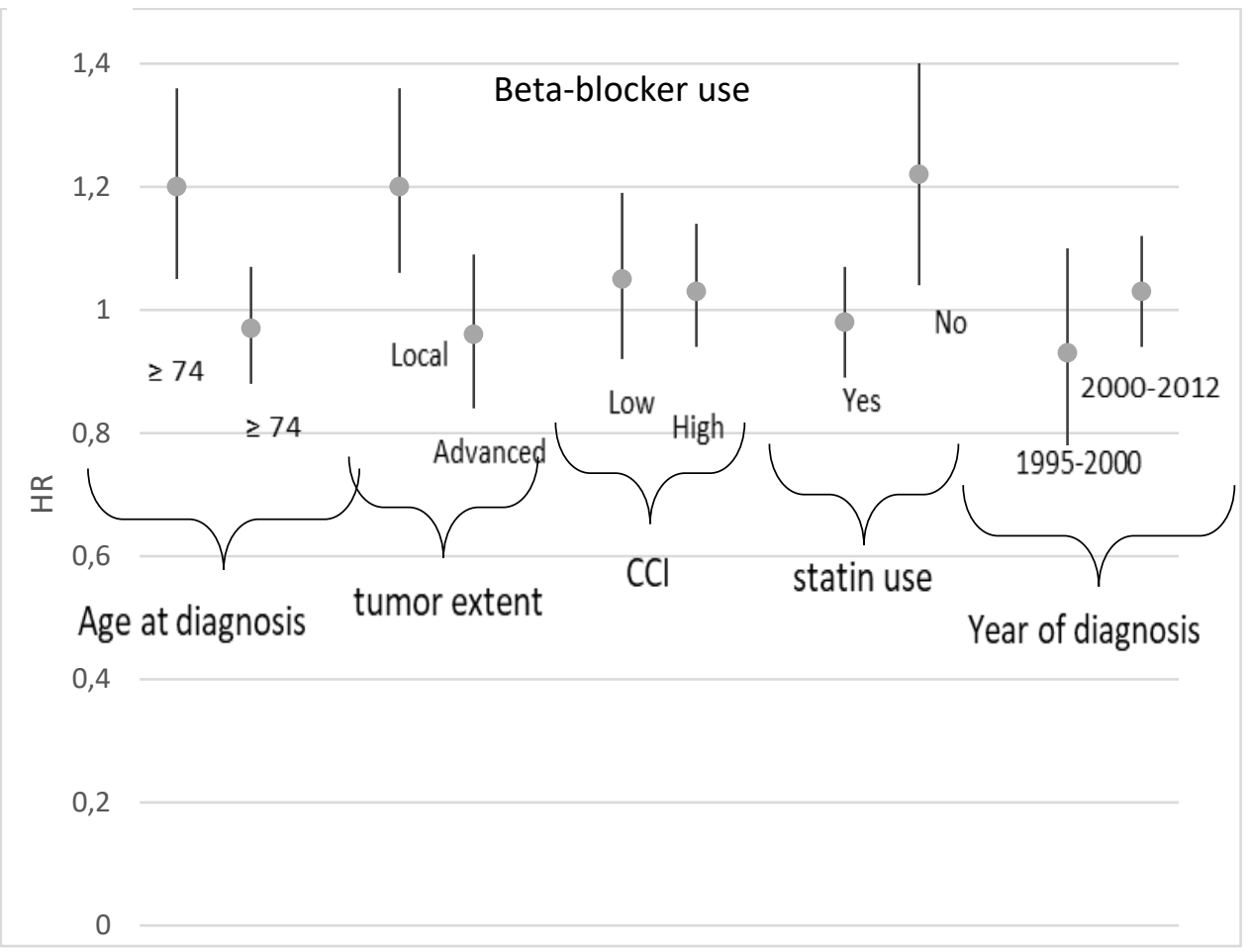

Figure 4. Risk of BCa death among calcium-channel blocker users. Stratified analyses with age at diagnosis, tumor extent, $\mathrm{CCl}$, statin use and year of $\mathrm{BCa}$ diagnosis.

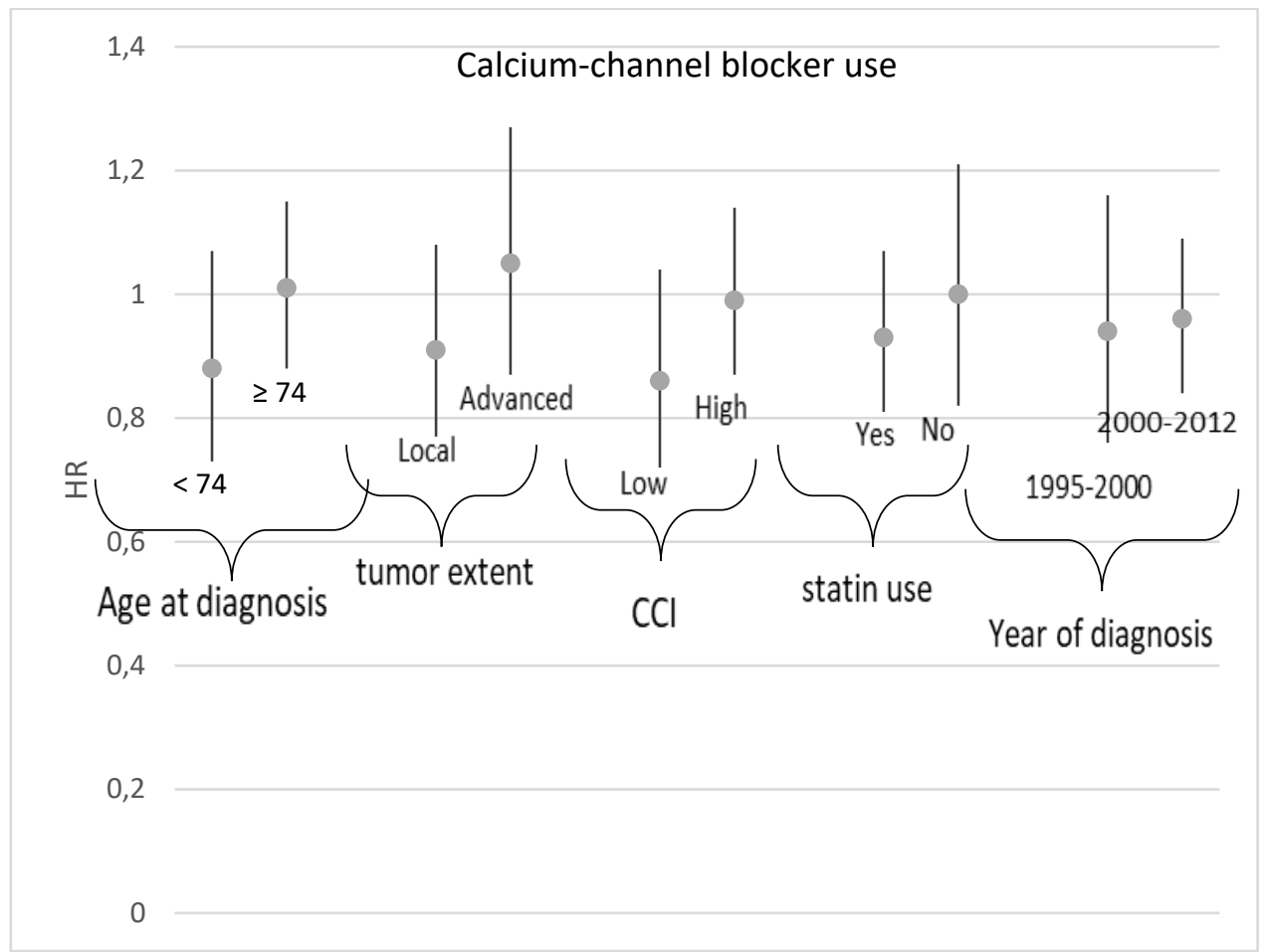


Figure 5. Risk of BCa death among diuretic users. Stratified analyses with age at diagnosis, tumor extent, $\mathrm{CCl}$, statin use and year of $\mathrm{BCa}$ diagnosis.

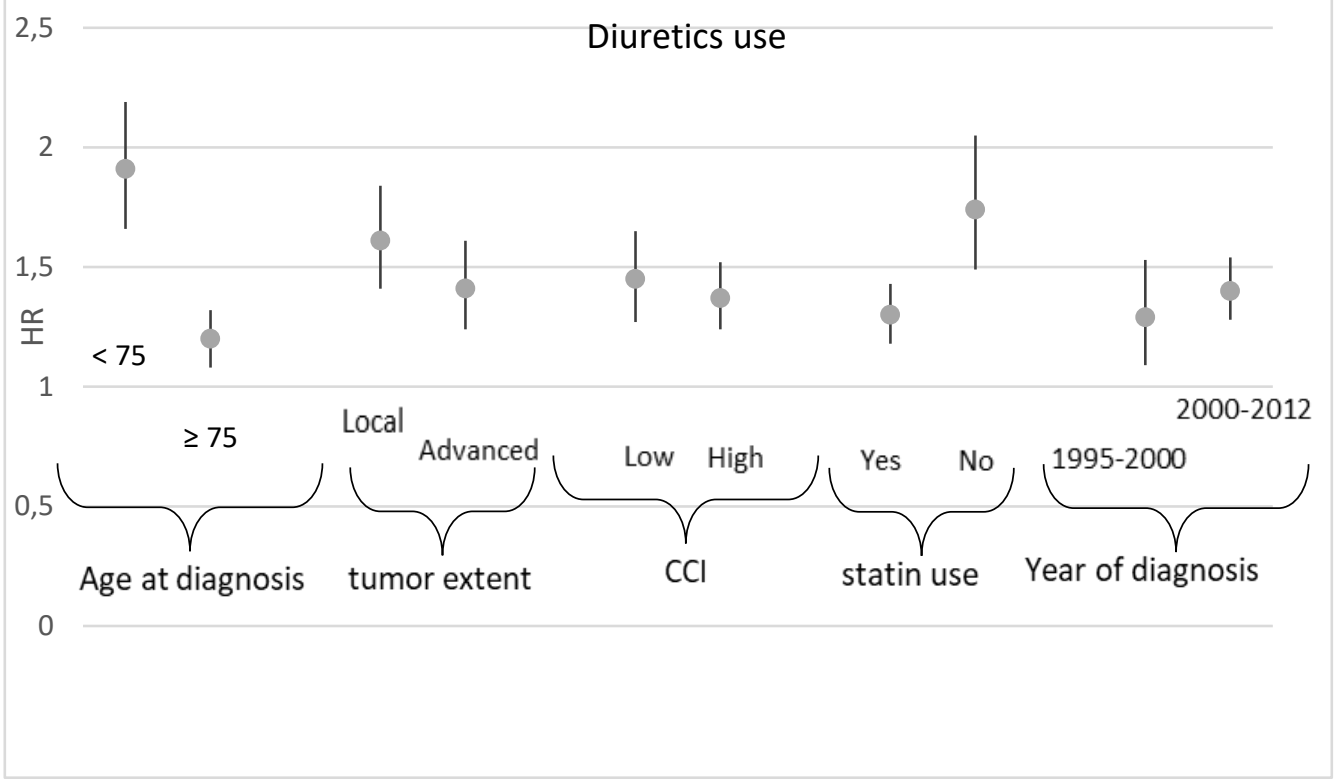

